\title{
Effectiveness of a Computerized Program in the Treatment of Dyslexia in a Sample of Fourth Grade Students
}

\author{
Yahya Hussain AL-Qatawneh ${ }^{1}$ \\ ${ }^{1}$ Faculty of Educational Sciences, The World Islamic Sciences and Education University, Amman, Jordan \\ Correspondence: Yahya Hussain AL-Qatawneh. E-mail: q_yahya2008@yahoo.com
}

Received: April 11, 2020

Accepted: May 27, $2020 \quad$ Online Published: June 12, 2020

doi:10.5539/ass.v16n7p15

URL: https://doi.org/10.5539/ass.v16n7p15

\begin{abstract}
Dyslexia is a specific learning disorder which has a neurobiological origin and is characterized by the presence of reading difficulties not accounted for by sensory, neurological, or intellectual deficits. Many researches indicated have conducted to study the effect of a computerized program to help students with dyslexia as it has proven its effectiveness in many fields. This study aimed to test the effectiveness of a computerized program in the treatment of dyslexia among the fourth grade students in a sample of Jordanian schools. The study sample consisted of (90) students in the fourth grade for the academic year 2017/2018. They were divided into two groups: a control group and an experimental group: 35 students and 55 students. This study was conducted through the introduction of an educational program to develop reading skills to address the difficulties of learning in reading, where learning is a necessary requirement because of its importance in the lives of students, so it was necessary to focus on learning to read to students at different levels of special needs, including those with learning disabilities who They may need some methods and strategies that suit their different learning styles. Therefore, this study came within the framework of teaching reading for people with learning difficulties in the basic stage. Provide teachers with training skills by training them in the use of the computer program in teaching reading skills, providing a theoretical background on the phenomenon of learning difficulties, especially in the field of reading, its causes and educational strategies for people with learning disabilities, and this helps to provide the necessary educational care for them.
\end{abstract}

Keywords: dyslexia, computer based training, learning difficulties, school, learning of disabilities, effectiveness

\section{Introduction}

Education has benefited from the inclusion of technology and computers by making it easier for students to keep up while helping teachers by improving the way lessons can be planned and taught. Students who use computers learn to use word processors for work, and subsequently they learn computer jargon and strengthen grammatical skills. Students can also look up lessons on websites or through email rather than lugging heavy textbooks with them every day. Students who use computers have been shown to attend school more steadily and perform better than students who do not use computers. Along with getting higher grades on exams, students also stated they felt more involved with their lessons and work if they used a computer. Using computers gets students to become more focused on their work at home, in collaborative projects with other students and on their own. Computers play a vital role in the modern business world, and many of even the most basic jobs involve technology and computers. Teaching students how to use computers helps them prepare for any number of possible careers, and classes based on computer education can get even more specific. Computers make the learning process a lot more simple and efficient, giving students access to tools and methods of communication unavailable offline. For example, students can check their grades or lesson plans online, and also communicate directly with their teachers via email or educational platforms such as Blackboard. Students can also send work to their teachers from home or anywhere else, letting them finish work outside the constraints of school hours and teaching them about procrastination and personal responsibility.

However, Dyslexia, also known as reading disorder, is characterized by trouble with reading despite normal intelligence.[2][7] Different people are affected to varying degrees.[4] Problems may include difficulties in spelling words, reading quickly, writing words, "sounding out" words in the head, pronouncing words when reading aloud and understanding what one reads.[4][8] Often these difficulties are first noticed at school.[3] When someone who previously could read loses their ability, it is known as alexia.[4] The difficulties are 
involuntary and people with this disorder have a normal desire to learn.[4]. Treatment involves adjusting teaching methods to meet the person's needs.[2] While not curing the underlying problem, it may decrease the degree of symptoms.[9] Treatments targeting vision are not effective.[10] Dyslexia is the most common learning disability and occurs in all areas of the world.[3][11] It affects 3-7\% of the population,[3][6] however, up to $20 \%$ may have some degree of symptoms.[12] While dyslexia is more often diagnosed in men,[3] it has been suggested that it affects men and women equally.[11] Some believe that dyslexia should be best considered as a different way of learning, with both benefits and downsides.[13][14]. Because computer is important in education this research aims to experiment using computer program in the treatment of dyslexia in a sample of fourth grade students.

\section{Objectives of the Study}

The present study aims to achieve the following objectives

1. Measure the effectiveness of the proposed computer program in the development of reading skills: (comprehension, analysis, and composition), in the fourth grade students whom had Dyslexia.

2. Measure the effectiveness of the proposed computer education program in developing reading skills: (comprehension, analysis, and composition) according to gender variable (male and female) to students in the fourth grade whom had Dyslexia.

\subsection{Study Hypotheses}

The present study is based on the following two main hypotheses:

1. There is no statistically significant difference at the level $(\alpha=0.05)$ between the mean scores of the students of the experimental and control groups on the test of achievement in reading skills (pronunciation, comprehension, analysis, and composition), in the post application, Computerized Tutorial

2. There is no statistically significant difference at the level $(\alpha=0.05)$ between the mean scores of male and female students in the experimental group on the level of achievement in reading skills (pronunciation, comprehension, analysis, and composition), in the post-test in regards with gender of the students.

\subsection{Study Approach}

The nature of the study and its objectives required the use of the experimental approach, which is one of the most appropriate methods of the study. "Experimental" is meant to change something, to note the effect of that change on something else; that is, to experiment with certain modifications or changes and to notice their effect on something else. The ultimate purpose of the experiment is learning; that is, learning its outcome, or the impact of the change it is making. From the point of view of scientific research, the experiment is a procedure aimed at verifying the relationship of the problem and the known, by dividing the number of individuals randomly in groups dealing with independent variable or more, and the main element in the experimental research is that the researcher intentionally puts the circumstances There are different groups of different experiences. In this case, the researcher used to divide the students randomly to deal with independent study variables in conditions determined by the nature of the study.

\subsection{Terminology of the Study}

Through the current study procedures, the following procedural definitions have been developed:

\subsection{Computerized Training Program}

Is a specific plan that includes a set of activities, exercises, exercises, experiences, situations and integrated activities in Macromedia Flash Animation, in order to train reading skills for students with learning disabilities in the fourth grade? The program has been prepared and designed by the researcher in coordination with specialists in the field of e-learning and programming, and implemented through the computer using the software Adobe (Adobe macromedia flash), so that the student can take the course material pictured on the computer screen, that enables him to return easily, and learn the result of learning the skills of reading and understanding of lessons, through images of reinforcement or stimuli to try once if not successful in the answer. This program is carefully designed to be easily dealt with and dealt with at school, at home or at any place where the device is available, because it promotes the principle of self-learning and interaction, and the role of the teacher is limited to supervision and guidance.

And adopted the researcher to programming the educational material assessed, because the student with learning 
difficulties often enter the learning resources room for two or three, where he learns reading and writing and "according to certain strategies, and then back to class to merge with his colleagues and follow with them the prescribed lessons. A lesson in the reading book, for example, has learned how to pronounce letters and words with the help of a computer when he was in the learning resources room, he can better follow his colleagues than before, and learn to read using a new strategy.

Strategy of education Computer-aided design, and designed the program, which consists of a set of displays that included:

- Title screen and the row assigned to it.

- The program's theoretical description screen shows the Student Guide screen and includes instructions to help the student interact with the program.

- The Teacher's Guide screen and some instructions for the resource room teachers on the program include the program objectives screen and include the educational objectives of the program as described in the teacher's guide.

- The lessons of the lessons, including the required paragraphs of the students with their area and with the voice of the full content, and the student can repeat the listening so that he can master the skill of the word and words in the reading level.

- Question screens, containing a set of objective questions on the lessons, accompanied by images and sounds that reinforce the correct answer, or ask the student to try again if he makes a mistake.

- The training screens include training the students in the skills of analysis and composition, and the skill of the calendar as it appears in the expression exercises that ask the student to express his opinion on a subject.

- Expression screens, including images representing the content of the expression of the student's intention to form sentences expressing his understanding of the subject.

\section{Learning Difficulties}

There are many definitions in which scientists strive to describe the state of learning disabilities. One of the most popular definitions is the definition of children with learning disabilities by the Federal Government of America, which states that "children with learning disabilities are deficient in one or more basic psychological processes which require understanding or use of written and spoken language. This lack of ability to listen, think, speak, read, write, spell or perform calculations is due to a disability in perception, Brain dysfunction, dyslexia, or dyslexia, and these learning difficulties may not be caused by visual, auditory, motor, mental retardation, emotional disorders, environmental, cultural, or economic deprivation. [1].

Learning disabilities are also known as the problems that people face in acquiring knowledge and skills to reach the normal level expected of those of the same age, especially because of mental disability or cognitive disorder. The term learning disabilities became prominent in the 1980s; it is extensive, covering general conditions such as Down's syndrome, as well as special circumstances, such as cognitive or neurological conditions, such as difficulty in reading and attention deficit disorder.dyslexia often have difficulty finding links between letters, sounds, and have problems with spelling, word recognition, and other symptoms of dyslexia: [3] Failure to understand what others are saying Fully. Difficulty in organizing written and spoken language. Delayed speech ability. Weak self-expression. Difficulty learning new vocabulary, either through reading or hearing. Difficulty learning foreign languages. Slow reading, as well as giving up long reading tasks. Difficult to understand questions, follow directions. Poor spelling. Difficulty keeping serial numbers. The problem of distinguishing left and right. This type of disorder is characterized by writing problems. This disorder may cause the child to be tense and awkward when carrying the pen. Other signs of this condition include: [3] great hatred of writing, drawing, or both. Problems with grammar. Difficult to write thoughts. Fast loss of energy, lack of attention as you write. The problem of writing ideas in logical sequence. Leave words incomplete, or delete them when you type sentences. Disagreement The signs of this difficulty include problems in understanding basic mathematical concepts such as fractions, numbers, positive and negative numbers, and may also include: [3] problem in currency conversion. Chaos solved math problems on paper. Problem identifying the logical information sequence. Problem understanding the time sequence of events. Difficulty in describing math operations verbally. Dysfunction The person who has this difficulty has some problems with motor tasks that can affect learning. These symptoms include: (3) problems of self-regulation, and other things of the person. Problem with tasks that require hand-eye coordination, such as coloring in lines, assembling puzzles, and cutting accurately. Weak balance. Breaking things. Sensitivity to loud noise, or repetitive sounds, such as clock beats [20]. 


\subsection{Reasons for Learning Difficulties}

There is no specific reason for learning difficulties, but researchers have some theories about why they evolved, including: Genetic influences: Experts have noted that learning disabilities tend to spread in families. They believe that heredity can play a role, But researchers are still debating whether learning difficulties are in fact genetic, or if they appear in families because of children's learning, and their imitation of their parents. Brain development: Some experts believe that learning difficulties can be attributed to brain growth, both before and after birth, so problems such as low birth weight, hypoxia, or premature birth can be related to learning difficulties. Those who receive head injuries are also at risk of learning difficulties [21]. Environmental impacts: Infants and young children are more vulnerable to environmental toxins; they may sometimes contribute to learning difficulties, and malnutrition at an early stage of life may also impede learning at a later stage [22].

\subsection{Characteristics of Children with Learning Difficulties}

There are a range of general characteristics of people with learning disabilities: [2] Cognitive Characteristics: A clear drop in the level of achievement in one or more of the basic academic subjects, is reading, writing, or math. Language characteristics: The child suffers from problems in receiving and understanding speech, and in expression, as well as may make mistakes in the composition of sentences, delete some words or make mistakes in grammatical formulation. Kinetic characteristics: A child with learning difficulties has problems with large movements such as running, jumping, picking up objects, and problems with fine movements such as scissors or writing. Social and behavioral characteristics: These include lack of self-control, rapid emotional changes, non-social behaviors, and social withdrawal. How to deal with children Learning difficulties Studies have shown the importance of the role of the family in dealing with the problem of learning difficulties in children and alleviate them, and showed that their role in influencing the child is much stronger than school, and that the family whenever the child is given appropriate attention, it achieves great successes in overcoming the problem, There are some points that can summarize the role of the family in dealing with the child: [1] Child observation, it is essential that parents follow their child's development and development continuously from school age to school, research and the question about any disturbing observation in the development of developmental child. Assess the child, make the decision to undergo assessment tests by specialists to ascertain the existence of the problem of learning difficulties or not, and give the specialist accurate answers to their questions on the child's case to be accurate diagnosis. Making positive decisions that relate to the future interests of the child after obtaining an assessment and making sure the problem exists, and determined to take responsibility for helping the child. Accept the child and help him to overcome the problem patiently, and not punish him for default and load a burden of higher than his capacity and abilities. Research, learning and take courses related to learning difficulties to understand the means and methods that may help to solve the problem and understand the types of programs and assistance offered to this class of children and students. Cooperation between parents and teachers or specialists in special education and the implementation of its instructions in accordance with the interests of the child.

How to deal with children with learning difficulties there are some tips to help teach children with learning disabilities:

To show a positive attitude toward the child and accept him, and to recognize the difference between him and others and not compare with others. Choose the teaching methods that will be easy on the child, focus on his strengths and not on the weaknesses. Keep away from mockery, reprimand and threatening behavior while dealing with a child [4]. Follow the process of learning by means of pictures, etc., and rely on the concrete things as much as possible in the education of the child and stay away from indoctrination as much as possible. Restrained and calm while teaching the child, show the packets to control the educational process, not to give the child room to control the teaching time. Adopting a method that addresses questions that stimulate thinking in the child. Identify tasks that fit the child's situation; do not be too large or too easy for him, and set a specific time to finish these tasks. You must choose a teacher who wants to work with children in this particular category, and be familiar with the methods of dealing and teaching. If the child fails to learn a skill, the method of teaching and other methods must be changed. If not, it should be replaced with a slightly simpler skill. Graduation must take place at the time of the dissolution of the duties. The tasks that require a little time are started, and this time is gradually increased for a longer time. Link new educational experiences with previous experiences. Make the child participate and participate in the selection of educational activities that he likes and starts with, for example [5]. Give the child sufficient time to answer or solve the exercise, etc. and not to rush him. Knowledge and knowledge of behavior modification methods to be used consistently with the child. Make daily plans ready for the child's application and follow up, and give him daily instructions and duties. VAKT is one of the most important methods in teaching a child with learning disabilities. It depends on making the child use all his senses 
together during his training. This method facilitates academic communication with the child and helps parents or teachers enrich the learning process to increase the comprehension. The child is more likely to learn, and this method is applied in the following example: "The child tells the teacher a short story, written by the teacher, the teacher asks the child to look at her. (Hearing) B (pronunciation), written by the child (touch and movement) [7].

\section{Learning Resource Rooms}

The Resource Room is a separate remedial classroom in any school where students with learning disabilities, such as some learning disabilities, are given direct and special education, academic treatment, help with homework [1] and related tasks, whether they are individuals or groups. Where the resource room contains many activities to help students with learning difficulties to overcome them as well as contain activities that help both the resource room teacher and the normal classroom teacher to deal effectively with students with difficulties in education and to understand the needs and identify the strengths and weaknesses, including room Sources:

- Tools and tests to diagnose the shortcomings of the student and determine the nature of treatment required.

- Methods of teaching appropriate to the nature of the difficulties experienced by the student.

- Educational materials appropriate to the nature of methods and methods of teaching.

- Teaching students in groups that take into account the type and degree of difficulty experienced by this group.

- Educational activities and tools that interest the learner and thus ensure his cooperation, participation and interaction.

- The schedules of the duration of each student in the resource room and in the regular classroom.

- Collaborative planning between the resource teacher, the regular classroom teacher and the educational counselor.

\section{Eligibility Test}

Is the test related to learning resulting from experiences in organized learning situations where attention is focused on the extent to which a course or program has been learned. It may be locally developed by the teacher, or a standardized collection test. The objective of this study is to prepare the subjects in the first two stages before applying the computer program and the other strategies. The second is after the completion of the application to find and analyze the results. . This test measures the reading skills of the course book in 2017/2018. And the test was applied to the control and experimental samples before and after learning the skills of reading both computerized and non-computerized.

\section{The limits of the study}

The current study was limited to:

1. Preparation of a computer program to teach reading skills for students with learning disabilities in the fourth grade, which includes three modules of the curriculum.

2. stop reading skills of the two main components; know the letters and words, and reading comprehension, and what falls within the skills of analysis, composition, application and evaluation, in students with learning disabilities, assisted by the computer, and using the software (macromedia flash animation, which is characterized by its coverage of different artistic aspects, as well as interactive. Because of the multiplicity of reading skills and their branches, the present study was limited to addressing the skills of comprehension, analysis and composition.

\section{Limitations of study sample:}

The study was applied to 90 students who were referred to specialized learning rooms for those with learning difficulties, male and female in the fourth grade, and were divided into two equal samples; experimental and control.

- Spatial Study Limitations: The study was implemented in the public schools of the basic stage, which includes specialized rooms for students with learning difficulties in the Amman region.

- Temporal study Limitations: The study was applied in the second semester of the academic year. $2017 / 2018$

\section{Study Tools:}

The researcher used a set of tools to implement the following procedures: 


\section{Computerized software}

Designed by the curriculum for the fourth grade, the program was implemented with the help of computer programmers.

Eligibility Test: It is prepared by the researcher, and included the measurement of reading skills

\section{Study plan and procedures:}

The researcher carried out the following procedures to complete the study:

1. Determine the theoretical framework for research through the study of educational literature, and previous studies related to the variables of the study

2. Building the test for reading skills, according to the curriculum for the fourth grade.

3. Computerized program design Education Reading skills, according to the curriculum for the fourth grade.

4. The preparation of the standards of trends and opinions, which were built according to the standards used in some studies after making adjustments to them in line with the purpose. And then presented to a group of arbitrators to determine the validity of the poor, and suitability to the current study.

5. Sample Study Sample: The study sample consisted of 90 students with learning disabilities identified in reading in the fourth grade

6. Conduct the implementation of the test for the academic achievement.

7. Application of the computerized program to teach the experimental group, and the non-computerized strategies of the control group.

8. Conduct the post-application to test the educational achievement.

9. Extract, analyze and process results to test the validity of hypotheses and answer their questions.

10. Interpret the results, submit proposals, and evaluate the study.

\section{Related Work}

The struggle experienced by people with rapid temporal processing of acoustic information concerns both speech (Tallal \& Stark, 1981) and non-speech sounds (Breier et al., 2001; Cantiani et al., 2009), such as music (Huss et al., 2011). Neuroimaging studies provide evidence of a significant overlap in the brain regions involved in processing the characteristics of both auditory speech and non-speech signals (Joanisse \& Gati, 2003; Brown et al., 2006; Musacchia et al., 2007; Schön et al., 2010; Abrams et al., 2011; James, 2012; Jantzen et al., 2014).

, Reviews of international dyslexia intervention studies explored the outcomes of treatment programmes and identified the basic ingredients for an effective treatment programme for dyslexia: training phoneme awareness, relating spoken and written language at the subword level and explicit tutored instruction (Foorman, Breier, \& Fletcher, 2003; Goetry, Nossent, \& Hecke van, 2006; Lin et al., 1999; National Reading Panel, 2000; Torgesen, 2005). These ingredients are combined in the Dutch National Protocols for Dyslexia Diagnostics and Treatment (Blomert, 2006) including training of phoneme awareness in combination with grapheme-phoneme association as the basis for a highly structured reading and spelling training at subword and word level.

Many studies also an association between music and reading skills. Musical expertise has a positive effect on language and literacy abilities in normal-reading children (Hurwitz et al., 1975; Douglas \& Willats, 1994; Anvari et al., 2002; Forgeard et al., 2008; Moreno et al., 2009; Degé \& Schwarzer, 2011; Brandt et al., 2012). Furthermore, in both normal-reading children and children with DD, music discrimination abilities, assessed using tonal-melodic and rhythmic tasks, predict phonological and reading skills (Forgeard et al., 2008). All these findings together suggest that interventions aimed at enhancing basic auditory perception skills of children with DD may impact language and reading abilities.

Two Dutch effect studies revealed that progress in clinical settings towards normalization of reading and spelling performance was possible (Gerretsen, Vaessen, \& Ekkebus, 2003; Tijms, Hoeks, Paulussen-Hoogeboom, \& Smolenaars, 2003). Phonological representation dysfunction is associated with difficulties in dynamic and rapidly changing auditory information processing (Tallal \& Stark, 1981; Tallal et al., 1985, 1993; Farmer \& Klein, 1995; Breier et al., 2003; Tallal, 2004; Corriveau et al., 2007; Huss et al., 2011). The primary deficit underlying DD is still under debate. Most likely, a combination of different factors is involved (Ramus, 2003; Pennington, 2006; Menghini et al., 2010). However, a specific impairment in phonological processing is still widely assumed to be the core deficit underlying DD, as confirmed by many substantive studies (Goswami, 2000; Snowling, 2000; Lyon et al., 2003; Ramus et al., 2003; Démonet et al., 2004; Ramus and Szenkovits, 2008; 
Fraser et al., 2010).

Children with DD also lack sensitivity to speech prosody (Corriveau et al., 2007; Goswami et al., 2010), pitch perception (Baldeweg et al., 1999; Goswami et al., 2011) and rhythm (Overy et al., 2003; Thomson \& Goswami, 2008; Corriveau \& Goswami, 2009; Huss et al., 2011; Goswami et al., 2013; Flaugnacco et al., 2014), which are sound attributes cued by amplitude, duration, and frequency changes of the acoustic signal. These basic auditory perceptual and timing difficulties could contribute to the development of impaired phonological representation for words, which is the distinctive feature of DD (Leong \& Goswami, 2014).

\section{Method and Procedures}

This section includes the study Approach, its variants, its society, the method of selecting its sample, the study tools and its design, the statistical treatments, and the application procedures, which are as follows:

\subsection{Study Approach}

The present study aimed at identifying the change in the sample of the students after exposure to a computer-aided learning program, comparing it with the non-computerized education strategies, and then comparing the results to the effect of applying the computerized program, which is the main experiment in the present study, Therefore, the researcher used the experimental method to prepare the necessary study tools and to select the sample of the study from the schools in which he will be tested. Therefore, my sample chose the experimental and control students with learning difficulties in the schools chosen to complete the steps of the experiment, by conducting the Pre test, and applying the experiment, which in the current study is a computerized educational program. And then conduct the test of achievement to make comparisons between students sample of the study before the experiment and then to verify the success of the experiment under study.

\subsection{Study Variables}

The study included the following variables:

The independent variables in this study are:

Method: Using computer software, and non - computerized methods 2. Sex: Male and Female

The dependent variable: the effect of the computerized program in - the achievement of students in reading skills

\subsection{Study Society}

The study population consists of fourth grade students with learning disabilities who are referred to the learning resource rooms in the public schools affiliated to the Directorate of Education.

\subsection{The Study Sample}

The sample of the study consisted of (90) students and students with learning disabilities in the schools of Zarqa Governorate, and those referred to the learning resource rooms according to the procedures followed, as these students have applied the diagnostic measures prescribed by the Ministry of Education. These measures include cognitive tests, family interviews, monitoring lists, and non-standardized collection tests that may be designed by resource room teachers, the department's supervision department, and intelligence tests (applied in some schools).

In the light of the determinants of the study, the researcher chose 90 students in the light of the determinants of a sample. He divided the group of students into two equal eyes; a pilot is applying a teaching program in computer-aided reading skills; another is a student who teaches reading skills by non-computerized methods; The distribution of pupils in the two study samples.

Table 1 . The distribution of pupils in the two study samples

\begin{tabular}{cccc}
\hline The group & Sex & Teaching method & The Number \\
\hline \multirow{2}{*}{ Experimental } & Male & Computerized & 20 \\
& Female & & 25 \\
Officer & Male & Traditional & 20 \\
& Female & & 25 \\
& Total & & 90 \\
\hline
\end{tabular}

The study aimed to identify the effectiveness of teaching reading skills for people with learning disabilities compared to the effectiveness of teaching in other ways. Based on the variables of the study, the researcher began to conduct the test of the skills of reading to be applied before and after the teaching of students in the sample of the experimental study skills reading with the help of the computer program, after the use of 
non-computerized methods with the students of the control sample.

\subsection{Statistical Processes}

The researcher used the Statistical Analysis Package for Social Sciences (SPSS), where the arithmetic mean and standard deviations were extracted, and the value of the analysis of the results of the test.

For the post-test, the comparison between the arithmetic averages and the significance level in the results obtained between the control and experimental groups on the one hand and between males and females in the experimental group were used on the other. T- Firmly and truthfully the test used the Pearson correlation coefficient, and the Kronbach alpha equation. The proportion of the arbitrators' agreement on the arbitration clauses of the measures of trends has adopted the arithmetical averages of their responses to the validity of the paragraphs. The arithmetical averages and the standard deviations have adopted the percentage of responses to these measures.

6.6 Skills Measured by the Test

- Understanding

- Analysis

- Installation

\section{Results and Discussion}

The aim of this study is to design a computerized educational program in the context of developing appropriate educational strategies for students with special needs, including those with learning disabilities. This program is designed to measure the effectiveness of learning in learning disabilities, reading skills, and its effectiveness in the attitudes of students, teachers, and parents towards computer-assisted learning. After applying the program, and analyzing the data, the researcher reached the following results:

\subsection{Results Related to Pre Experiment}

To ensure equality of the experimental group and the control group in terms of level of achievement, the researcher conducted the achievement test Pre, and was extracted arithmetic means and standard deviations for the performance of students of the experimental group and control group according to their gender as follows:

Table 2. The analysis of the test results of the experimental and control groups

\begin{tabular}{cccccccc}
\hline The group & $\begin{array}{c}\text { The } \\
\text { Number }\end{array}$ & Mean & $\begin{array}{c}\text { Standard } \\
\text { Deviation }\end{array}$ & $\begin{array}{c}\text { Standard } \\
\text { error }\end{array}$ & Value t & $\begin{array}{c}\text { Degree of } \\
\text { freedom }\end{array}$ & $\begin{array}{c}\text { Level of } \\
\text { significance }\end{array}$ \\
\hline Experimental & 50 & 47.35 & 5.54 & 1.25 & 0.324 & 52 & 0.849 \\
Control & 50 & 48.98 & 3.25 & 1.14 & & \\
\hline
\end{tabular}

Since the arithmetic average of the experimental group $=47.354$, and the arithmetic mean of the control group $=$ 48.984 , and the value of $\mathrm{T}=0.324$, which is not statistically significant at the level of significance, where the level of significance $=0.849$. So there are no significant differences between the groups in the results of the pre test, indicating that the two groups are equal.

Results on the first hypothesis of the study This hypothesis states that: There is no difference of statistical significance at the level $=0.05$ ) between the average scores of the students of the experimental and control groups on the achievement test in reading skills ( comprehension, analysis, and composition), in the post-test, is attributed to the application of the computerized educational program. To verify this hypothesis, the mean and standard deviations of the total scores were first extracted from the experimental and control groups in the post-test. And then comparing the signs of the two groups in reading skills: comprehension, analysis, and composition as follows:

Table 3. Mathematical averages, standard deviations of the total score and reading skills in the post-test

\begin{tabular}{|c|c|c|c|}
\hline & The group & Mean & Standard Deviation \\
\hline Total mark & Experimental & 69 & 6.4 \\
\hline Skill & Control & 47 & 7.5 \\
\hline \multirow{2}{*}{ The comprehension skills } & Experimental & 66 & 8.1 \\
\hline & Control & 54 & 7.0 \\
\hline \multirow{2}{*}{ The analysis skills } & Experimental & 61 & 7.3 \\
\hline & Control & 44 & 6.4 \\
\hline
\end{tabular}


composition Skills

$\begin{array}{ccc}\text { Experimental } & 70 & 9.8 \\ \text { Control } & 49 & 6.1\end{array}$

The above table shows that the mean of the total score was greater for the benefit of the experimental group (22). And the arithmetic averages. The reading skills analyzed were as follows: In the verbal skill, the arithmetic average was greater for the control group by (12) marks. In the comprehension skill, the arithmetic average was greater for the experimental group with about 14. In the analysis skill, the arithmetic average was greater for the experimental group with about (31) marks. In the skill of composition, the arithmetic mean was greater for the experimental group with about (21) marks. These averages indicate the superiority of the experimental group on the control group, the total score, and the reading skills scores analyzed by the study, namely: understanding, analysis, and composition. The arithmetic mean of verbal skill was greater for the control group.

To find out the significance of these differences, $\mathrm{T}$ - Test was used as shown below, With regard to the total marks of the post-test of the experimental and control groups, the results were as in the following table:

Table 4. Shows the comparison of the post-test markers of the experimental and control groups

\begin{tabular}{cccccccc}
\hline The group & $\begin{array}{c}\text { Number of } \\
\text { students }\end{array}$ & Mean & $\begin{array}{c}\text { Standard } \\
\text { Deviation }\end{array}$ & $\begin{array}{c}\text { Standard } \\
\text { error }\end{array}$ & Value t & $\begin{array}{c}\text { Degree of } \\
\text { freedom }\end{array}$ & $\begin{array}{c}\text { Level of } \\
\text { significance }\end{array}$ \\
\hline Experimental & 30 & 69 & 7.82 & 1.52 & 0.416 & -8.136 & 0.000 \\
Control & 30 & 47 & 10.81 & 2.06 & &
\end{tabular}

Comparing the arithmetical averages of the experimental and control groups, it was found that the difference between the arithmetic averages of the experimental and control groups in the post-test; For the benefit of the experimental group and the value of $\mathrm{T}=0.416$ and the level of significance $=0.000$ at the level of significance $(\alpha$ $=0.05)$, so there are significant differences between the two groups in the results of the post-test, interest experimental group.

\subsection{Results for the Second Hypothesis of the Study}

The hypothesis is as follows: There is no statistically significant difference at the level $(\alpha=0.05)$ between the mean scores of males and females of the experimental group on the scale of achievement in reading skills (verbal, comprehension, analysis, and composition), in the post-application, is attributed to the sex of pupils. To verify this hypothesis, the mean scores and standard deviations of the overall scores were extracted from the male students in the experimental group and compared with the results of the females in the post-test. And then compare the male signs of female signs in reading skills: pronunciation, comprehension, analysis, and composition in the post-test, as follows:

Table 5. Shows the comparison of male signs with female signs of the experimental group in the post-test

\begin{tabular}{cccccccc}
\hline Total marks & $\begin{array}{c}\text { Number of } \\
\text { students }\end{array}$ & Mean & $\begin{array}{c}\text { Standard } \\
\text { Deviation }\end{array}$ & $\begin{array}{c}\text { Standard } \\
\text { error }\end{array}$ & Value t & $\begin{array}{c}\text { Degree of } \\
\text { freedom }\end{array}$ & $\begin{array}{c}\text { Level of } \\
\text { significance }\end{array}$ \\
\hline Male & 20 & 58 & 8.52559 & 2.00128 & & & \\
Female & 25 & 71 & 9.21851 & 2.07031 & -3.214 & 24 & .000 \\
\hline
\end{tabular}

Table (5) shows that the male arithmetic average of male performance in the experimental group reached the post-test (58) compared to the average female performance (71), which is the largest (13) mark. And the value of $\mathrm{T}=-3.214$, with a significance level of 0.000 , which is statistically significant at the level $(\alpha=0.05)$ for females.

\section{Discussion of Results}

This study attempted to identify the effectiveness of a computer program to teach the reading skills of a sample of students with reading disabilities in the third grade. In order to achieve this goal, a computer program was designed to read and prepare an achievement test to measure reading skills in the experimental and control sample, before and after teaching pupils the skills of reading in two ways, and not computerized. Through the use of the statistical program (SPSS) to extract the results related to the courses of study, the study reached a series of results that were exposed in the previous chapter. In this chapter, an analysis of those two related to the study arrangements will be made.

\subsection{Discussion of Results Related to Tribal Testing}

The results showed that the value of $\mathrm{T}=260$, which is not statistically significant at the level of significance ( $\alpha=$ $0.05)$, so there are no significant differences between the groups in the results of the tribal test, Indicates that the 
two groups are equal.

Discuss the area results with the first hypothesis of the study:

As for the first hypothesis of the study, which states that there is no statistically significant difference at the level $(\alpha=0.05)$. Among the average scores of the experimental and control groups on the test of learning achievement in reading skills (pronunciation, comprehension, analysis, and composition), in the post-application. The mean and standard deviations of the experimental and control groups were extracted. The mean of the students' performance in the experimental group compared with the average control group performance was greater by 26 points. The mean of the students' performance in the experimental group compared to the average performance of the control group in the cognitive skill of the experimental group was (22). The mean of the students' performance in the experimental group compared with the average control group performance in the analysis skill was greater in the experimental group by (31). The mean of the students' performance in the experimental group compared to the average performance of the control group in the skill of composition was greater in the experimental group by (21) marks. This is an indication of:

- Students with learning difficulties in this study tend to use new teaching strategies in learning reading skills.

- The ability of students with learning disabilities participating in this study to learn computer-aided reading skills.

- The interactive component of the computer program can be used to teach learning disabilities as it is used for ordinary students, with the difference in how training is prepared and focused.

- The design of the program, which was based on the transfer of the textbook as it is, with a change in the method of assessment to suit the abilities of students with learning difficulties, make students ask to return the words and sentences that they did not mastered from the first time, to avoid their mistakes in the answer to questions, Or to dissolve the exercises, the student was afraid every time of the phrase (try again). In other words, the accompanying reinforcement method had a positive and effective role in trying to acquire the skills accurately and avoid mistakes as much as possible. The principle of reinforcement is the foundation of programmed education.

- Students with learning difficulties on the computer lab are motivated to drive towards learning. Computer programs, including pictures, sounds and movements, can be considered as a means of learning through play.

- The results of the experimental sample students on the results of students in the control sample may be due to the fact that the use of computers in education helps to reduce the problem of ADHD among people with learning disabilities in general.

Table 6. A comparison of male signs with female marks shows the skill of pronunciation in the post-test of the experimental group

\begin{tabular}{cccccccc}
\hline $\begin{array}{c}\text { kill marks } \\
\text { pronunciation }\end{array}$ & $\begin{array}{c}\text { Number of } \\
\text { students }\end{array}$ & Mean & $\begin{array}{c}\text { Standard } \\
\text { Deviation }\end{array}$ & $\begin{array}{c}\text { Standard } \\
\text { error }\end{array}$ & $\begin{array}{c}\text { Value } \\
\mathrm{t}\end{array}$ & $\begin{array}{c}\text { Degree of } \\
\text { freedom }\end{array}$ & $\begin{array}{c}\text { Level of } \\
\text { significance }\end{array}$ \\
\hline Male & 20 & 39 & 5.91 & 2.7 & -1.58 & 24 & .046 \\
Female & 25 & 48 & 6.74 & 3.9 & & & \\
\hline
\end{tabular}

Table (6) shows that the mean average male performance in verbal skill in the experimental group was in the post-test (39) compared to the average female performance (48), which is the largest (9) marks and the value of $\mathrm{T}=-1.58$, and the level of significance $=0.046$, which is significant at the level $(\alpha=0.05)$ for the benefit of females.

Table 7. The comparison of male signs with female marks shows the skill of understanding in the post-test of the experimental group

\begin{tabular}{cccccccc}
\hline $\begin{array}{c}\text { Signs of understanding } \\
\text { skill }\end{array}$ & $\begin{array}{c}\text { Number of } \\
\text { students }\end{array}$ & SMA & $\begin{array}{c}\text { Standard } \\
\text { Deviation }\end{array}$ & $\begin{array}{c}\text { Standard } \\
\text { error }\end{array}$ & Value t & $\begin{array}{c}\text { Degree of } \\
\text { freedom }\end{array}$ & $\begin{array}{c}\text { Level of } \\
\text { significance }\end{array}$ \\
\hline Male & 20 & 37 & 15.91 & 3.49 & -2.375 & 24 & .034 \\
Female & 25 & 59 & 12.50 & 3.88 & & \\
\hline
\end{tabular}


Table (7) shows that the mean average male performance in verbal skill in the experimental group was in the post-test (37) compared to the average female performance (59), which is the largest (22) marks and the value of $\mathrm{T}=-2.375$, and the level of significance $=0.034$, which is significant at the level $(\alpha=0.05)$ for the benefit of females.

Table 8. The comparison of male signs with female marks shows the skill of analysis in the post-test of the experimental group

\begin{tabular}{cccccccc}
\hline $\begin{array}{c}\text { Signs of skill } \\
\text { analysis }\end{array}$ & $\begin{array}{c}\text { Number of } \\
\text { students }\end{array}$ & Mean & $\begin{array}{c}\text { Standard } \\
\text { Deviation }\end{array}$ & $\begin{array}{c}\text { Standard } \\
\text { error }\end{array}$ & Value t & $\begin{array}{c}\text { Degree of } \\
\text { freedom }\end{array}$ & $\begin{array}{c}\text { Level of } \\
\text { significance }\end{array}$ \\
\hline Male & 20 & 52 & 8.74 & 2.41 & -2.375 & 24 & .038 \\
Female & 25 & 69 & 4.82 & 1.57 & & 24 \\
\hline
\end{tabular}

Table (8) shows that the mean average male performance in verbal skill in the experimental group was in the post-test (52) compared to the average female performance (69), which is the largest (17) marks and the value of $\mathrm{T}=-2.375$, and the level of significance $=0.038$, which is significant at the level $(\alpha=0.05)$ for the benefit of females.

Table 9. A comparison of male signs with female marks shows the skill in the post-test of the experimental group

\begin{tabular}{cccccccc}
\hline $\begin{array}{c}\text { Skill marks } \\
\text { composition }\end{array}$ & $\begin{array}{c}\text { Number of } \\
\text { students }\end{array}$ & Mean & $\begin{array}{c}\text { Standard } \\
\text { Deviation }\end{array}$ & $\begin{array}{c}\text { Standard } \\
\text { error }\end{array}$ & Value t & $\begin{array}{c}\text { Degree of } \\
\text { freedom }\end{array}$ & $\begin{array}{c}\text { Level of } \\
\text { significance }\end{array}$ \\
\hline Male & 20 & 57 & 7.46 & 2.64 & -3.984 & 24 & .000 \\
Female & 25 & 72 & 4.29 & 1.85 & & & \\
\hline
\end{tabular}

Table (9) shows that the mean average male performance in verbal skill in the experimental group was in the post-test (57) compared to the average female performance (72), which is the largest (15) marks. And the value of $\mathrm{T}=-3.984$, and the level of significance $=0.000$, which is significant at the level $(\alpha=0.05)$ for the benefit of females.

\subsection{Discussion of the Results of the Second Hypothesis of the Study}

This hypothesis states that there is no statistically significant difference at the level $(\alpha=0.05)$ between the mean scores of male and female students of the experimental group on the scale of achievement in reading skills: (pronunciation, comprehension, analysis, and composition). The post-application, is attributed to the sex of pupils.

On the basis of the results, the mean of the female signs in the total score was greater than the male signs by (9) marks.

The arithmetic mean of female scores in the skill scores was greater than that of males by 17 marks. The arithmetic mean of female marks in the skill marks was greater than that of males by 15 marks.

These results can be explained by the following:

1. 1 - the superiority of the results of females on the males within the experimental group appears to be consistent with the observed superiority of females to males in the acquisition of language skills, where researchers see the superiority of females in the male language skills, and the proportion of males who suffer from reading difficulties greater than females, Many believe that females are better able to perform verbal tasks than males who excel in tasks based on spatial cognition and mechanical understanding. McCupey and Jacqueline, who have compiled huge facts in this field, confirm that there are significant differences in language development. Females remain superior to males until the third year of age, where males are attached to them, girls regain their high school graduates around the age of 11, and in another study that supported girls from an early age with clear superiority in language ability. The observations made on all children, both normal and articulate and weak-headed, showed that females began to speak before males. It was also found that at all ages the incidence of speech disorders or reading delays was significantly lower in girls than in boys. Girls have shown consistent superiority in reading speed, similar words and tables, complementing and rearranging sentences, and the superiority of girls in many facets of brute intelligence may be attributed to the great extent they have in linguistic and verbal aspects.

2. The results of females in the experimental group outweigh the results of females in the control group. 
3. Male results in the experimental group were higher than those in the control group due to the variable teaching method, indicating that students with learning difficulties - male and female - were more likely to learn to read using new strategies that could lead to better educational outcomes.

\section{Study Proposals}

Some suggestions were made in the light of the study's findings

1. Invest the computer program in teaching reading skills, which proved effective in the presentation of lessons, and the method of evaluation.

2. Conduct more research and field studies in the field of learning difficulties, not for the sake of study and to benefit the researcher, as much as the goal is to serve people with learning difficulties already.

3. The preparation of educational programs for children with special needs, including those with learning disabilities, to help them overcome some of the academic problems they suffer from.

4. Emphasize the need to train teachers and teachers of special education, including teachers and teachers of learning resource rooms on the use of computers in the education of students who deal with them.

5. Conducting research studies for a number of studies in the field of computerized education for people with special needs for long periods, as in the case of some foreign studies, because of its usefulness through which the evaluation of Arab studies and the development of work in the fields of special education.

6. The possibility of benefiting from the program in the future in the field of training teachers in the use of computers in education.

\section{References}

Abrams, D. A., Bhatara, A., Ryali, S., Balaban, E., Levitin, D. J., \& Menon, V. (2011). Decoding temporal structure in music and speech relies on shared brain resources but elicits different fine-scale spatial patterns. Cereb. Cortex 21, 1507-1518. https://doi.org/10.1093/cercor/bhq198

Antonietti A. (2009). Why is music effective in rehabilitation? In A. Gaggioli, E. Keshner, P. L. Weiss, \& G. Riva (Eds.), Advanced Technologies in Neurorehabilitation (pp. 179-194). Amsterdam: IOS Publisher.

Anvari, S. H., Trainor, L. J., Woodside, J., \& Levy, B. A. (2002). Relations among musical skills, phonological processing, and early reading ability in preschool children. Exp. Child Psychol., 83, 111-130. https://doi.org/10.1016/S0022-0965(02)00124-8

Bakker, D. J., Licht, R., \& Kappers, E. J. (1995). Hemisphere-specific treatment of dyslexia. In G. Tramontana, \& S. R. Hooper (Eds.), Advances in Child Neuropsychology (Vol. 3, pp. 144-177). New York, NY; Berlin: Springer-Verlag.

Baldeweg, T., Richardson, A., Watkins, S., Foale, C., \& Gruzelier, J. (1999). Impaired auditory frequency discrimination in dyslexia detected with mismatch evoked potentials. Ann. Neurol., 45, 495-503.

Banks, A. (1999). The Effects of Music Instruction on the Visual Perception of Students with Dyslexia or Other Reading Problems. Thesis, Virginia State University.

Brandt, A., Gebrian, M., \& Slevc, L. R. (2012). Music and early language acquisition. Front. Psychol. 3, 327. https://doi.org/10.3389/fpsyg.2012.00327

Breier, J. I., Fletcher, J. M., Foorman, B. R., \& Klaas, P. (2003). Auditory temporal processing in children with specific reading disability with and without attention deficit/hyperactivity disorder. J. Speech Lang. Hear. Res. 46, 31-42. https://doi.org/10.1044/1092-4388(2003/003)

Breier, J. I., Gray, L., Fletcher, J. M., Diehl, R. L., Klaas, P., \& Foorman, B. R., et al. (2001). Perception of voice and tone onset time continua in children with dyslexia with and without attention deficit/hyperactivity disorder. J. Exp. Child Psychol. 80, 245-270. https://doi.org/10.1006/jecp.2001.2630

Brown, S., Martinez, M. J., \& Parsons, L. M. (2006). Music and language side by side in the brain: A PET study of the generation of melodies and sentences. Eur. J. Neurosci. 23, 2791-2803. https://doi.org/10.1111/j.1460-9568.2006.04785.x

Cancer, A., \& Antonietti, A. (2011). Integrazione del metodo sublessicale per la dislessia con attività ritmico-musicali (Integrating the sublexical methods for dyslexia with rhtimical-musical activities), in Proceedings of the XX Congresso Nazionale dell'Associazione Italiana per la Ricerca e Intervento nella Psicopatologia dell'Apprendimento (AIRIPA) “I disturbi dell'apprendimento" (Prato:), 107. 
Cantiani, C., Lorusso, M. L., Valnegri, C., \& Molteni, M. (2009). Perception of non-verbal auditory stimuli in Italian dyslexic children. Dev. Neuropsychol. 35, 115-123. https://doi.org/10.1080/87565640903335955

Cazzaniga, S., Re, A. M., Cornoldi, C., Poli, S., \& Tressoldi, P. E. (2005). Dislessia e Trattamento Sublessicale [Dyslexia and Sublexical Treatment]. Trento: Erickson.

Chandrasekaran, C., Trubanova, A., Stillittano, S., Caplier, A., \& Ghazanfar, A. A. (2009). The natural statistics of audiovisual speech. PLoS Comput. Biol. 5, e1000436. https://doi.org/10.1371/journal.pcbi.1000436

Cogo-Moreira, H., Andriolo, R. B., Yazigi, L., Ploubudis, G. B., Brandão de Ávila, C. R., \& Mari, J. J. (2012). Music education for improving reading skills in children and adolescents with dyslexia. Cochrane Database Syst. Rev. 8, CD009133. https://doi.org/10.1002/14651858.CD009133.pub2

Cornoldi, C., \& Colpo, G. (1995). Nuove Prove di Lettura MT per la Scuola Media Inferiore [New MT Reading Tests for Junior High School]. Firenze: Organizzazioni Speciali.

Corriveau, K., \& Goswami, U. (2009). Rhythmic motor entrainment in children with speech and language impairment: Tapping to the beat. Cortex, 45, 119-130. https://doi.org/10.1016/j.cortex.2007.09.008

Corriveau, K., Pasquini, E., \& Goswami, U. (2007). Basic auditory processing skills and specific language impairment: A new look at an old hypothesis. J. Speech Lang. Hear. Res., 50, 647-666. https://doi.org/10.1044/1092-4388(2007/046)

Degé, F., \& Schwarzer, G. (2011). The effect of a music program on phonological awareness in preschoolers. Front. Psychol. 2, 124. https://doi.org/10.3389/fpsyg.2011.00124

Démonet, J. F., Taylor, M. J., \& Chaix, Y. (2004). Developmental dyslexia. Lancet, 363, 1451-1460. https://doi.org/10.1016/S0140-6736(04)16106-0

Douglas, S., \& Willats, P. (1994). The relationship between musical ability and literacy skills. J. Res. Read., 17, 99-107. https://doi.org/10.1111/j.1467-9817.1994.tb00057.x

Draper, P. (2007). The Effect of Music, Gestures, and Music with Gestures on the Sight-word Recognition of Students with Dyslexia. Thesis, Florida State University.

Farmer, M. E., \& Klein, R. M. (1995). The evidence for a temporal processing deficit linked to dyslexia: A review. Psychon. Bull. Rev. 2, 460-493. https://doi.org/10.3758/BF03210983

Fiveash, D. (1995). Music as an Educative Enrichment Medium for the Remediation of Children with Reading Problems. Thesis, University of Cape Town.

Flaugnacco, E., Lopez, L., Terribili, C., Zoia, S., Buda, S., \& Tilli, S., et al. (2014). Rhythm perception and production predict reading abilities in developmental dyslexia. Front. Hum. Neurosci. 8, 392. https://doi.org/10.3389/fnhum.2014.00392

Forgeard, M., Schlaug, G., Norton, A., Rosam, C., Lyengar, U., \& Winner, E. (2008). The relation between music and phonological processing in normal-reading children and children with dyslexia. Music Percept. 4, 383-390. https://doi.org/10.1525/mp.2008.25.4.383

Fraser, J., Goswami, U., \& Conti-Ramsden, G. (2010). Dyslexia and specific language impairment: The role of phonology and auditory processing. Sci. Stud. Read. 14, 8-29. https://doi.org/10.1080/10888430903242068

Germagnoli, S., Bonacina, S., Cancer, A., \& Antonietti, A. (in press). Dislessia e musica: dai meccanismi comuni ai trattamenti (Dyslexia music: From common mechanisms to treatments). Dislessia.

Goswami, U. (2000). Phonological representations, reading development and dyslexia: Towards a $\begin{array}{lllll}\text { cross-linguistic theoretical } & \text { framework. } & \text { Dyslexia } & 6, & 133-151 .\end{array}$ https://doi.org/10.1002/(SICI)1099-0909(200004/06)6:2<133::AID-DYS160>3.0.CO;2-A

Goswami, U., Fosker, T., Huss, M., Mead, N., \& Szûcs, D. (2011). Rise time and formant transition duration in the discrimination of speech sounds: The Ba-Wa distinction in developmental dyslexia. Dev. Sci. 14, 34-43. https://doi.org/10.1111/j.1467-7687.2010.00955.x

Goswami, U., Gerson, D., \& Astruc, L. (2010). Amplitude envelope perception, phonology and prosodic sensitivity in children with developmental dyslexia. Read. Writ. 23, 995-1019. https://doi.org/10.1007/s11145-009-9186-6

Goswami, U., Huss, M., Mead, N., Fosker, T., \& Verney, J. P. (2013). Perception of patterns of musical beat distribution in phonological developmental dyslexia: Significant longitudinal relations with word reading and reading comprehension. Cortex, 49, 1363-1376. https://doi.org/10.1016/j.cortex.2012.05.005 
Hurwitz, I., Wolff, H. P., Bortnick, B. D., \& Kokas, K. (1975). Nonmusical effects of the Kodaly music curriculum in primary grade children. J. Learn. Disabil. 8, 164-174.

Huss, M., Verney, J. P., Fosker, T., Mead, N., \& Goswami, U. (2011). Music, rhythm, rise time perception and developmental dyslexia: Perception of musical meter predicts reading and phonology. Cortex, 47, 674-689. https://doi.org/10.1016/j.cortex.2010.07.010

Jaarsma, B., Ruijssenaars, A., \& den Broeck, W. (1998). Dyslexia and learning musical notation: A pilot study. Ann. Dyslexia, 48, 137-154.

James, C. E. (2012). Music and language processing share behavioral and cerebral features. Front. Psychol. 3, 52. https://doi.org/10.3389/fpsyg.2012.00052

Jantzen, M. G., Howe, B. M., \& Jantzen, K. J. (2014). Neurophysiological evidence that musical training influences the recruitment of right hemispheric homologues for speech perception. Front. Psychol. 5, 171. https://doi.org/10.3389/fpsyg.2014.00171

Joanisse, M. F., \& Gati, J. S. (2003). Overlapping neural regions for processing rapid temporal cues in speech and nonspeech signals. Neuroimage, 19, 64-79. https://doi.org/10.1016/S1053-8119(03)00046-6

Kraus, N., \& Chandrasekaran, B. (2010). Music training for developmental auditory skills. Nat. Rev. Neurosci., 11, 599-605. https://doi.org/10.1038/nrn2882

Leong, V., \& Goswami, U. (2014a). Assessment of rhythmic entrainment at multiple timescales in dyslexia: Evidence for disruption to syllable timing. Hear. Res., 308, 141-161. https://doi.org/10.1016/j.heares.2013.07.015

Leong, V., \& Goswami, U. (2014b). Impaired extraction of speech rhythm from temporal modulation patterns in speech in developmental dyslexia. Front. Hum. Neurosci. 8, 96. https://doi.org/10.3389/fnhum.2014.00096

Lorusso, M. L., Facoetti, A., \& Bakker, D. J. (2011). Neuropsychological treatment of dyslexia: Does type of treatment matter? J. Learn. Disabil. 44, 136-149. https://doi.org/10.1177/0022219410391186

Lorusso, M. L., Facoetti, A., Paganoni, P., Pezzani, M., \& Molteni, M. (2006). Effects of visual hemisphere-specific stimulation versus reading-focused training in dyslexic children. Neuropsychol. Rehabil. 16, 194-212. https://doi.org/10.1080/09602010500145620

Lyon, G. R., Shaywitz, S. E., \& Shaywitz, B. A. (2003). A definition of dyslexia. Ann. Dyslexia, 53, 1-14. https://doi.org/10.1007/s11881-003-0001-9

MacGinitie, W. H., MacGinitie, R. K., Maria, K., \& Dreyer, L. G. (2000). Gates-MacGinitie Reading Tests-Directions for Administration (levels $7 / 9$ \& 10/12) (4th ed.). Rolling Meadows, IL: Riverside.

Menghini, D., Finzi, A., Benassi, M., Bolzani, R., Facoetti, A., \& Giovagnoli, S., et al. (2010). Different underlying neurocognitive deficits in developmental dyslexia: A comparative study. Neuropsychologia, 48, 863-872. https://doi.org/10.1016/j.neuropsychologia.2009.11.003

Moreno, S., Marques, C., Santos, A., Santos, M., Castro, S. L., \& Besson, M. (2009). Musical training influences linguistic abilities in 8-year-old children: More evidence for brain plasticity. Cereb. Cortex, 19, 712-723. https://doi.org/10.1093/cercor/bhn120

Musacchia, G., Sams, M., Skoe, E., \& Kraus, N. (2007). Musicians have enhanced subcortical auditory and audiovisual processing of speech and music. Proc. Nat. Acad. Sci. U.S.A. 40, 15894-15898. https://doi.org/10.1073/pnas.0701498104

Muter, V., Hulme, C., \& Snowling, M. J. (1997). The Phonological Abilities Test. London: Psychological Corporation.

Nicolson, R. I., \& Fawcett, A. J. (1996). The Dyslexia Early Screening Test. London: The Psychological Corporation.

Overy, K. (2003). Dyslexia and music: From timing deficits to musical intervention. Ann. N.Y. Acad. Sci., 999, 497-505. https://doi.org/10.1196/annals.1284.060

Overy, K., Nicolson, R. I., Fawcett, A. J., \& Clarke, E. F. (2003). Dyslexia and music: Measuring musical timing skills. Dyslexia, 9, 18-36. https://doi.org/10.1002/dys.233

Pennington, B. F. (2006). From single to multiple deficit models of developmental disorders. Cognition, 101, 385-413. https://doi.org/10.1016/j.cognition.2006.04.008 
Ramus, F. (2003). Developmental dyslexia: Specific phonological deficit or general sensorimotor dysfunction? Curr. Opin. Neurobiol., 13, 212-218. https://doi.org/10.1016/S0959-4388(03)00035-7

Ramus, F., \& Szenkovits, G. (2008). What phonological deficit? Q. J. Exp. Psychol. 61, 129-141. https://doi.org/10.1080/17470210701508822

Ramus, F., Rosen, S., Dakin, S. C., Day, B. L., Castellote, J. M., \& White, S. et al. (2003). Theories of developmental dyslexia: Insights from a multiple case study of dyslexic adults. Brain, 126, 841-865. https://doi.org/10.1093/brain/awg076

Register, D., Darrow, A. A., Standley, J., \& Swedberg, O. (2007). The use of music to enhance reading skills of second grade students and students with reading disabilities. J. Music Ther. 44, 23-37. https://doi.org/10.1093/jmt/44.1.23

Schön, D., Gordon, R., Campagne, A., Magne, C., Astésano, C., \& Anton, J. L., et al. (2010). Similar cerebral networks in language, music and song perception. Neuroimage, 51, 450-461. https://doi.org/10.1016/j.neuroimage.2010.02.023

Snowling, M. J. (2000). Dyslexia. Oxford: Blackwell.

Snowling, M. J., \& Hulme, C. (2012). The nature and classification of reading disorders. A commentary on proposals for DSM-5. J. Child Psychol. Psychiatry, 53, 593-607. https://doi.org/10.1111/j.1469-7610.2011.02495.x

Stambak, M. (1951). Problems of rhythm in the development of the child and in developmental dyslexia. Enfance, 4, 480-502. https://doi.org/10.3406/enfan.1951.1202

Tallal, P. (2004). Improving language and literacy is a matter of time. Nat. Rev. Neurosci. 5, 721-728. https://doi.org/10.1038/nrn1499

Tallal, P., \& Gaab, N. (2006). Dynamic auditory processing, musical experience and language development. Trends Neurosci. 7, 382-290. https://doi.org/10.1016/j.tins.2006.06.003

Tallal, P., \& Stark, R. E. (1981). Speech acoustic cue discrimination abilities of normally developing and language-impaired children. J. Acoust. Soc. Am. 69, 568-574. https://doi.org/10.1121/1.385431

Tallal, P., Miller, S., \& Fitch, R. H. (1993). Neurobiological basis of speech: A case for the preeminence of temporal processing. Ann. N.Y. Acad. Sci. 682, 27-47. https://doi.org/10.1111/j.1749-6632.1993.tb22957.x

Tallal, P., Stark, R. E., \& Mellits, E. D. (1985). Identification of language-impaired children on the basis of rapid perception and production skills. Brain Lang. 25, 314-322. https://doi.org/10.1016/0093-934X(85)90087-2

Thomson, J. M., \& Goswami, U. (2008). Rhythmic processing in children with developmental dyslexia: Auditory and motor rhythms link to reading and spelling. J. Physiol. Paris, 102, 120-129. https://doi.org/10.1016/j.jphysparis.2008.03.007

Tressoldi, P. E., Vio, C., Lorusso, M. L., Facoetti, A., \& Iozzino, R. (2003). Confronto di efficacia ed efficienza tra trattamenti per il miglioramento della lettura in soggetti dislessici [A comparison of the efficacy of the treatments to improve reading skills in dyslexic subjects]. Psicol. Clin. Sviluppo, 7, 481-494.

Wechsler, D. (1993). Wechsler Objective Reading Dimensions. London: The Psychological Corporation.

Wolff, P. H. (2002). Timing precision and rhythm in developmental dyslexia. Read. Writ. 15, 179-206. https://doi.org/10.1023/A:1013880723925

World Health Organization. (1992). The ICD 10 Classification of Mental and Behavioural Disorders: Clinical Descriptions and Diagnostic Guidelines. Geneva: World Health Organization.

Zoccolotti, P., De Luca, M., Di Filippo, G., Judica, A., \& Spinelli, D. (2005). Prova di Lettura di Parole e Non Parole [Test for reading of words and pseudo-words]. Rome: IRCCS Fondazione Santa Lucia.

\section{Copyrights}

Copyright for this article is retained by the author(s), with first publication rights granted to the journal.

This is an open-access article distributed under the terms and conditions of the Creative Commons Attribution license (http://creativecommons.org/licenses/by/4.0/). 